\title{
The Collapse Of The German Democratic Republic And The Future Of European Socialism An Interview with Dr. Gregor Gysi
}

\section{William A. Pelz}

During a visit to the United States this spring, the leader of Germany's Party of Democratic Socialism (PDS), Dr. Gregor Gysi, shared his thoughts on recent events in Europe and future problems. Gregor Gysi, the son of Jewish anti-Nazi resistance fighters, is a leading figure in the former East Germany known for his defense of political dissidents. Now, as leader of the 150,000 member PDS, Gysi ranks as one of the most respected members of the German Bundestag. His party, which received $16.33 \%$ of the votes cast in the 1990 DDR (East German) parliamentary election, currently enjoys the support of $30 \%$ of east German voters according to a recent poll.

Although little known in North America, Gysi is celebrated among the European left. For instance, well-known Russian socialist author, Boris Kagarlitsky, had this to say about Gysi: "The PDS is the most positive and significant thing to come out of the Eastern European left, and Gysi is the most brilliant leader to emerge from this experience. Without the PDS, progress for the left will be much more difficult in the next few years in Germany, as well as in Europe as a whole." Further, Marxist scholar Ernest Mandel even went so far as to say "Gregor Gysi may be the most important and capable German socialist leader since Paul Levi."

The importance of Gysi and the PDS has been noted by the mainstream press at times. Henry Kamm, writing in the New York Times (17 March 1990), observed: "The former Communist Party [SED], now called the Party of Democratic Socialism, wound up its campaign tonight for Sunday's first free parliamentary elections in East Germany with the largest and most enthusiastic rallies the capital has seen. Gregor Gysi, the party chairman, drew the biggest crowds and the most spontaneous approval of any East German political leader, not only at a mass rally on Alexanderplatz in the center of the capital, where some 10,000 showed up, but also throughout a busy day of campaigning."

"Among East Germany's largely novice native politicians, it is Mr. Gysi, a Berlin lawyer, who has carved out the most distinctive and popular profile ... [at an appearance at Humboldt University on the same day] Mr. Gysi delighted his student public with a full display of his natural, non-oratorical self, which some here compare to Woody Allen."

Even the West German Die Welt (14 December 1989) had to admit Gregor Gysi "is certainly one of the intellectually most polished opponents of re-unification." Meanwhile, the Frankfurter Allgemeine Zeitung, (5 December 1989) gave the following portrait:"Whether in elegant dark suit in the TV studio or with the workers" cap he wears in street demonstrations since Honecker's fall, Gregor Gysi, the clear-thinking jurist whose political and juristic arguments are equally persuasive, always present anywhere in the DDR where the deep crisis of the SED and where it is going is talked about and considered. The 41-year old son of the long-time publishing-house director, culture minister, ambassador and state secretary for church questions, Klaus Gysi, is chair of a commission, for the investigation of violations of 
the Party Statute and against the law committed by former and present functionaries of the SED."

Since unification, Gysi has been active in the defense of the rights of workers, women, immigrants and gays. His speeches in the German parliament are widely considered, even by political opponents, to be insightful and penetrating. Yet political life is far from easy for Gysi and the PDS as the mass media now alternately ignores or slanders him and his party as retreaded Stalinists. This conservative campaign has so far been successful as the PDS has been largely unable to gain significant support outside of eastern Germany.

$$
\text { t l } 1
$$

WP: You are certainly one of the most important leaders of the European left having distinguished yourself as a fighter for the rights of all oppressed groups.

Gysi: Such praise. To speak so highly of myself is no longer allowed in my own party, after the experiences of the last forty years.

WP: Still, few have rose to the serious challenge posed by the events of recent years. What do you think about the collapse of the Soviet Bloc?

Gysi: Yes, the situation is indeed fairly serious and given that I want to say something about the role of the left in Germany and in Europe I have perhaps to begin with the failure of state socialism in East Europe. It still exists in Cuba and China. So I have to concentrate on Europe. And we haven't seen it yet in the United States. State socialism as it has existed in Eastern Europe it has failed justifiably. It has failed with justification in that it has not accomplished the main objective, which is to say human emancipation. The main issue was not that the east was economically weaker than the west. If the people in the east had felt themselves so included in the form of socialism then they would not have wanted to let it go. State socialism did not accept the challenge before which we stand: it had no ecological ideas, it had no concept of democracy, and it had no idea of the gradual dismantling of power and thereby the gradual realization of human emancipation. By saying that, I do not mean to include myself amidst the generally discreditation of state socialism. But especially as socialists we are obliged to reflect on our pasts especially critically; because only if we try to learn something out of the experience will the experience have been worth something.

WP: So, you would say that the experience of State Socialism was mainly negative from a socialist viewpoint?

Gysi: The existence of the Soviet Union and Eastern bloc, of course, has certain accomplishments to its name. The first accomplishment is that, in my opinion, colonialism would not have collapsed as quickly as it did without the Soviet Union as it did with the Soviet Union. The second accomplishment is that the Soviet Union played a large part in destroying German fascism. The third accomplishment of state socialism is that it showed that a society can exist with much less social differences amongst the people than the social differences in capitalism exist. And State socialism especially in the DDR saw to it that there was a certain level of social security, a social net. And there were certain elements of daily life that were taken care of independent of a person's income, for example, accommodation, education and culture. So we can learn something from the experience of what socialism has 
accomplished, and we can learn something from the reasons that socialism failed: the structures which it implemented.

WP: Is the collapse of so many enterprises in the east since unification an indictment of state socialism?

Gysi: In part, many collapsed because they were inefficient and poorly managed. But many productive enterprises were shut down because the West German corporations wanted to eliminate competition. Not everything in the old DDR was worthless, much could have been saved.

WP: Why do you think that the left was unable to transform the DDR onto a truly socialist direction?

Gysi: In September 1989, it was much too late for us to be making the attempt to reform the old Communist party in East Germany and to move in the direction of the changes coming from the Soviet Union. Our primary objective was to insure an independent East Germany, and in that regard we failed, and naturally a reformed East Germany. Our second attempt was, well then if that does not work let's at least work towards an honorable reunification, and in that regard we failed. And now we stand before the task of having to transform all of Germany to socialism, and that of course is much more difficult.

WP: How were you able to transform the old Stalinist SED into a democratic Socialist party?

Gysi: It is almost impossible to describe the difficulty in trying to transform a state party apparatus into an opposition party. When I became chairman of the East German communist party, there were 44000 officials, now there are 150 . Tens of thousands were fired at a time when there was no such thing as unemployment insurance. At its peak the East German communist party had 2.3 million members, and now we have approximately 150000 members.

WP: Why has the PDS lost so many members now that it is an open party?

Gysi: Those members who have left the party have left for various reasons. Amongst them there are those who I am very sorry to see go. With some it was a bitter disappointment which drove them to leave. For some our reforms were not quick enough. For others they were too quick. Many left because they were worried about their social existence. But a very large group left because they remained true to themselves. That is to say for the same reasons they entered the party they left the party. Because when they joined the party they joined because one had to do it in order to get a job, and when they left the party they left because one had to leave the party to get a job. And in that regard I do not hold it against them, they were consistent with themselves. So in a certain sense I am grateful for the external pressure that was exerted on the party because that rid us of these people whom we otherwise would not have been able to get rid of.

WP: Specifically, how does the PDS differ from the old Stalinist SED?

Gysi: Throughout this whole time when so much was changing structurally we had to look for a new program for the party, and we had to look for new democratic structures within the party. I think we have since then established one of the most modern party constitutions. We do not necessarily always live in accordance with the 
constitution, but at least we have made the first important step, which is establishing a constitution. Something that is quite unusual for a German party. Three points: one can become a party member when you are sixteen, foreigners can become members of the party, and those people who declare themselves to be sympathizers with the party can enjoy almost all the privileges accorded by the party, and they can even become delegates to the party congress, which is to say as chairman of the party I was elected by amongst others, non-party members. Anyone who knows Germany knows what an historical leap that is.

WP: Would you still consider the PDS a communist party or, as some have said, have you moved towards social democracy?

Gysi: As far as the party program is concerned starting in 1989 we decided that we wanted to base our program on the communist, the socialist, the social democratic, and the pacifist traditions of the German and international workers movement. And to do that we had to decide to become a pluralist party, that is entirely atypical for Marxist parties. And those who base themselves on these four principles then in the end have to deal with it, and that can make life very difficult. We have members who consider themselves communist, people who consider themselves social democrats, Christians are in the party, pacifists without any religious background, and then a few people who do not define themselves in any particular way at all, like me for example. Which is to say that we recognize that one can proceed through various ways in order to practise a leftist politics. So that in this way, in recognizing that through various paths and from different sources and directions we can come to programmatic positions and opinions.

WP: That sounds very positive, but could you explain what the PDS's goal is?

Gysi: The starting point for our program is the question of humanity around the world. Because we believe that the species of human being is seriously threatened on this planet. And because we believe that the answers to these questions and threats will not come from the right. And we certainly do not believe that capitalism has been victorious over state socialism, it has only remained after the other is gone. It is equally incapable of addressing these questions of humanity, indeed it makes them worse. After the disappearance of the east-west conflict, there has been a rise of nationalism of the old racist variety. This remains a great threat today.

WP: Why have so many young people been attracted to the far right?

Gysi: Although multinational corporations understand that nationalism has nothing to do with profit, too many young people get caught up in the simple explanations the far right offers. Nationalism itself is irrational. Why should I feel pride in the work of Schiller or Goethe but not Shakespeare? I contributed nothing to any of their creations but can enjoy all equally.

WP: How can this irrational movement be fought?

Gysi: What is needed is a global movement against racism and for social justice which will lead to the emancipation of the individual. This is not merely a moral question because if something is not done to fight racism, to protect workers' standard of living and save the environment, everyone will suffer. 